\title{
Systemy ekspertowe w działalności bibliotecznej i informacyjnej: stan badań, problemy badawcze, przykłady zastosowań
}

\author{
Jolanta Szulc \\ Instytut Bibliotekoznawstwa i Informacji Naukowej \\ Uniwersytet Śląski
}

\begin{abstract}
Abstrakt
Teza/cel artykułu: Celem artykułu jest odpowiedź na pytania, czy i w jakim zakresie systemy ekspertowe są stosowane obecnie w działalności bibliotecznej i informacyjnej. Zwrócono uwagę na następujące elementy procesu informacyjnego: gromadzenie, przechowywanie i opracowanie informacji (charakterystyka wyszukiwawcza dokumentu, instrukcja wyszukiwawcza), wyszukiwanie informacji (kwerenda informacyjna, pytania w języku naturalnym), przekazywanie i wdrażanie informacji.

Metody badań: Przeprowadzono analizę literatury przedmiotu, zgromadzonej na podstawie kwerend w wybranych bazach danych. Wskazano kierunki badań nad systemami ekspertowymi, jako jednej z metodologii zarządzania wiedzą, wykorzystującej metody sztucznej inteligencji: rozwiązywanie problemów z reprezentacją wiedzy (generowanie, wartościowanie i zarządzanie wiedzą, ekstrakcja i synteza wiedzy w konstrukcji ekspertyzy), „samouczenie się”, ocena wydajności. Zastosowanie systemów ekspertowych omówiono na wybranych przykładach. Podjęto próbę określenia możliwych obszarów ich zastosowań w bibliotekach i ośrodkach informacji.

Wyniki: Na podstawie zgromadzonych materiałów, opracowano stan badań nad systemami ekspertowymi. Omówiono słownictwo dotyczące systemów ekspertowych, prezentowane w przykładowym tezaurusie.

Wnioski: Analiza ilościowa literatury przedmiotu wykazała znaczny spadek piśmiennictwa poświęconego systemom ekspertowym po 2010 r. Tym niemniej systemy ekspertowe (eksperymentalne, eksploatowane) są stosowane w wielu dziedzinach. Przewiduje się, że systemy te znajdą zastosowanie w bibliotekach specjalistycznych, w zakresie gromadzenia i kodyfikacji wiedzy w wybranych obszarach specjalizacji.
\end{abstract}

\section{Słowa kluczowe}

Systemy ekspertowe. Informacja naukowa. Nauka o informacji. Inżynieria wiedzy.

Otrzymany: 31.12.2013. Poprawiony: 3.06.2014. Zaakceptowany: 5.06.2014.

\section{Wstęp}

Systemy ekspertowe należą do grupy systemów inteligentnych, przeznaczonych do rozwiązywania specjalistycznych problemów, które wymagają profesjonalnej ekspertyzy. Inteligentne zachowania, obejmujące percepcję, rozumowanie, uczenie, komunikację i działanie w złożonych środowiskach, są przedmiotem badań zarówno kongnitywistyki, jak i sztucznej inteligencji (Kwaśnicka, 2000). Budowa użytecznych systemów, które wykazują i naśladują inteligentne zachowania, jest podstawowym celem sztucznej 
inteligencji. Obecnie najczęściej wyróżnia się cztery grupy systemów inteligentnych (Grosz \& Davis, 2011):

- inteligentne systemy symulacyjne (ISS, ang. Intelligent Simulations System)

- specjalistyczne systemy pozyskiwania informacji (IRSS, ang. Intelligent Information Resources System)

- inteligentne kreatory projektów (IPC, ang. Intelligent Project Coaches)

- zespoły robotów (RT, ang. Robot Teams).

W artykule zwrócono szczególną uwagę na specjalistyczne systemy pozyskiwania informacji.

Bibliotekarstwo i działalność informacyjna są dziedzinami, w których systemy ekspertowe mogą znaleźć zastosowanie. Mogą one służyć m.in. w takich działaniach praktycznych, jak wybór bazy danych odpowiedniej do przeprowadzenia danej kwerendy, klasyfikacja dokumentów i obiektów informacyjnych, katalogowanie. Mogą być też stosowane w badaniach naukowych i edukacji informacyjnej.

Celem artykułu jest odpowiedź na pytanie, czy i w jakim zakresie systemy ekspertowe są stosowane obecnie w bibliotekarstwie i informacji naukowej. Dla realizacji tego celu przeprowadzono analizę literatury przedmiotu. Przeszukano wybrane bazy danych, a na przykładzie bazy INSPEC zaprezentowano adekwatne do analizowanej problematyki słownictwo dostępne w tezaurusie tej bazy. W dalszej części artykułu omówiono reprezentowane w literaturze przedmiotu tematy i kierunki badań oraz przykłady zastosowań systemów ekspertowych. W zakończeniu podjęto próbę określenia możliwych obszarów zastosowań w bibliotekach i ośrodkach informacji.

\section{Pojęcie systemu ekspertowego}

Systemy ekspertowe zaliczane do czwartej generacji systemów informacyjnych, zawierają bazy wiedzy (ang. knowledge base), w których informacje są przechowywane w postaci symbolicznej. System informacyjny definiuje się jako

uporządkowany układ odpowiednich elementów, charakteryzujących się pewnymi właściwościami oraz połączonych wzajemnie określonymi relacjami (Cieciura, 2006, 34).

Cytowany autor zaznacza też, że elementami systemu informacyjnego są: nadawcy i odbiorcy informacji, zbiory informacji, kanały informacyjne oraz metody i techniki przetwarzania informacji.

Z kolei system ekspertowy - to dowolny program komputerowy, który na podstawie szczegółowej wiedzy może wyciągać wnioski i podejmować decyzje, działając w sposób zbliżony do zachowania człowieka. W programie do rozwiązywania problemów zlecanych ekspertom, wspomagającym podejmowanie decyzji, można wyróżnić: bazę wiedzy - zawierającą wiedzę dziedzinową istotną dla podejmowanych decyzji oraz system wnioskujący korzystający z bazy wiedzy dla wypracowania tych decyzji (Rutkowski, 2005).

Strukturę funkcjonalną systemu ekspertowego tworzą: baza wiedzy, system wnioskujący, dynamiczna baza danych, edytor bazy wiedzy oraz łącze użytkownika (Niederliński, 2000, 17). System ekspertowy uważa się za system działający zgodnie z paradygmatem: system ekspertowy = baza wiedzy + mechanizm wnioskowania + dialog z użytkownikiem. 
W angielskiej i polskiej literaturze przedmiotu na oznaczenie systemów tego typu są stosowane wyrażenia synonimiczne lub bliskoznaczne:

system ekspertowy = program regułowy = program $z$ regułowa bazq wiedzy;

expert system $=$ knowledge based system $=$ rule based system .

Inne spotykane w piśmiennictwie polskim określenia to: system ekspercki, system doradczy, system z bazq wiedzy, system wspomagania decyzji.

\section{Badania nad wykorzystaniem systemów ekspertowych}

Już na początku lat 90. przewidywano, że systemy ekspertowe mogą znaleźć zastosowanie w zarządzaniu rekordami, oprowadzaniu po bibliotece, doradztwie zawodowym, tworzeniu wykazu rozdziału materiałów bibliotecznych, doradztwie społecznym dla czytelników (Pindlowa, 1991).

Systemy ekspertowe znalazły zastosowanie w sektorach gospodarczych i przemysłowych, a także w sektorze opieki medycznej. Nie dziwi zatem fakt, że podejmowane były badania także nad ich wykorzystaniem w bibliotekach i ośrodkach informacji. Badania nad wykorzystaniem systemów ekspertowych w pracach bibliotecznych i dokumentacyjnych dotyczyły katalogowania, klasyfikowania, indeksowania, wyszukiwania informacji i obsługi bibliograficznej czytelników. W końcu lat 80. XX w. Barbara Sosińska-Kalata wyróżniła następujące dziedziny zastosowania systemów ekspertowych: prace administracyjne, podejmowanie decyzji związanych z zarządzaniem biblioteką, rutynowe prace biblioteczne oraz obsługa informacyjna użytkownika (Sosińska-Kalata, 1990). W połowie lat 90. XX w. podobny zestaw obszarów zastosowań systemów ekspertowych w bibliotekarstwie i usługach informacyjnych wyróżnili Dewendra K. Singh, Bhupendra K. Singh i Yogendra P. Dubey, wskazując iż służą one wspieraniu prac administracyjnych, zarządzania kadrami, planowania, katalogowania, klasyfikacji, gromadzenia zbiorów oraz usług informacyjnych (Singh et al., 1996).

W 1997 r. opublikowano wyniki badań piśmiennictwa poświęconego systemom ekspertowym stosowanym w bibliotekarstwie i informacji naukowej, w ramach których dokonano analizy 422 artykułów zebranych na podstawie wyszukiwania w bazach danych (LISAPlus, ERIC, INSPEC, DAO). W wyodrębnionej próbie piśmiennictwa: 232 artykuły (55\%) dotyczyły kwestii zastosowania systemów ekspertowych w informacyjnych usługach publicznych (poszukiwania i uzyskania informacji), 70 (17\%) - w procesach bibliotecznych (katalogowaniu, klasyfikowaniu), 25 (6\%) - w tworzeniu abstraktów i indeksowaniu, 16 (4\%) - w gromadzeniu zbiorów, 12 artykułów (3\%) sklasyfikowano w ramach grupy tematycznej „Systemy ekspertowe i sztuczna inteligencja”, a 67 artykułów (15\%) uznano za ogólne omówienia tematyki wykorzystywania tego typu systemów w działalności bibliotecznej i informacyjnej (Silva, 1997).

Poniżej omówiono wyniki podobnych badań przeprowadzonych przez autorkę niniejszego artykułu.

\section{Wyszukiwanie i selekcjonowanie literatury przedmiotu}

Badania dotyczące piśmiennictwa poświęconego systemom ekspertowym przeprowadzone zostały w kwietniu 2011 r. na podstawie poszukiwań w bazach danych rejestrujących 
publikacje z zakresu bibliotekoznawstwa i informacji naukowej, informatyki, elektroniki, matematyki, sterowania, medycyny. Wykorzystano bazy danych dostępne w systemie OneLog, dystrybuowanym przez Bibliotekę Uniwersytetu Śląskiego. Wybrane bazy zawierają abstrakty artykułów z czasopism, konferencji, książek, raportów, dysertacji lub umożliwiają korzystanie z pełnych tekstów dokumentów dostępnych w ponad 20 językach. Zasięg chronologiczny badań obejmował piśmiennictwo rejestrowane od 1940 r., zgodnie z zasięgiem chronologicznym przeszukiwanych baz. Ze względu na to, że przeszukwania przeprowadzone zostały w pierwszej połowie 2011 r., dane dotyczące piśmiennictwa opublikowanego w tym roku są niepełne. Wymienione są one w tabeli 1, w której podano też liczbę rekordów znalezionych za pomocą poszczególnych słów kluczowych oraz ich koniunkcyjnego połączenia.

Tabela 1. Wyniki wyszukiwania według słów kluczowych expert systems i information science w wybranych bazach danych (dostęp: 1.04.2011)

\begin{tabular}{|c|c|c|c|c|}
\hline Lp. & $\begin{array}{l}\text { Nazwa bazy } \\
\text { (zasięg) }\end{array}$ & $\begin{array}{l}\text { Rodzaj } \\
\text { indeksu }\end{array}$ & Słowa kluczowe & $\begin{array}{c}\text { Liczba } \\
\text { rekordów }\end{array}$ \\
\hline 1 & 2 & 3 & 4 & 5 \\
\hline \multirow{3}{*}{1} & \multirow{3}{*}{ INSPEC (1969-) } & \multirow{3}{*}{ Keywords } & expert systems & 48147 \\
\hline & & & information science & 12350 \\
\hline & & & expert systems AND information science & 123 \\
\hline \multirow{3}{*}{2} & \multirow{3}{*}{$\begin{array}{l}\text { Library and In- } \\
\text { formation Science } \\
\text { Abstracts (1969-) }\end{array}$} & \multirow{3}{*}{ Keywords } & expert systems & 1795 \\
\hline & & & information science & 12034 \\
\hline & & & expert systems AND information science ${ }^{1}$ & 70 \\
\hline \multirow{3}{*}{3} & \multirow{3}{*}{$\begin{array}{l}\text { MasterFILE Pre- } \\
\text { mier (1975-) }\end{array}$} & \multirow{3}{*}{$\begin{array}{l}\text { Subject } \\
\text { Terms }\end{array}$} & expert systems & 365 \\
\hline & & & information science & 5198 \\
\hline & & & expert systems AND information science & 4 \\
\hline \multirow{3}{*}{4} & \multirow{3}{*}{ MatSciNet (1940-) } & \multirow{3}{*}{$\begin{array}{l}\text { Review } \\
\text { Text }\end{array}$} & expert systems & 444 \\
\hline & & & information science & 251 \\
\hline & & & expert systems AND information science & 3 \\
\hline \multirow{3}{*}{5} & \multirow{3}{*}{ MEDLINE (1963-) } & \multirow{3}{*}{ Topic } & expert systems & 3291 \\
\hline & & & information science & 635 \\
\hline & & & expert systems AND information science ${ }^{2}$ & 4 \\
\hline \multirow{3}{*}{6} & \multirow{3}{*}{$\begin{array}{l}\text { Science Direct } \\
(1995-)\end{array}$} & \multirow{3}{*}{ Keywords } & expert systems & 1481 \\
\hline & & & information science & 86 \\
\hline & & & expert systems AND information science ${ }^{3}$ & 5 \\
\hline
\end{tabular}

${ }^{1}$ Wyniki wyszukiwania dla: KW=(expert systems) and $\mathrm{KW}=$ (information science).

2 Wyniki wyszukiwania dla: $($ Topic $=($ expert $)$ AND Topic $=($ systems $))$ AND $($ Topic $=($ information $)$ AND Topic $=($ science $)$ ).

${ }^{3}$ Wyniki wyszukiwania dla: (keyword=(expert systems) AND (information science)). 


\begin{tabular}{|c|c|c|c|c|}
\hline 1 & 2 & 3 & 4 & 5 \\
\hline \multirow{3}{*}{7} & \multirow{3}{*}{ SCOPUS (1966-) } & \multirow{3}{*}{ Keywords } & expert systems & 43839 \\
\hline & & & information science & 55446 \\
\hline & & & expert systems AND information science & 702 \\
\hline \multirow{3}{*}{8} & \multirow{3}{*}{ Web of Knowledge } & \multirow{3}{*}{ Topic } & expert systems & 14892 \\
\hline & & & information science & 5089 \\
\hline & & & expert systems AND information science 5 & 21 \\
\hline
\end{tabular}

Liczba rekordów bibliograficznych zawierających informację o systemach ekspertowych i rejestrowanych w wybranych bazach danych wynosiła ogółem 114254. Łączna liczba rekordów bibliograficznych rejestrujących piśmiennictwo dotyczące informacji naukowej wynosiła 91 089, a łączna liczba rekordów wyszukanych według wyrażenia złożonego expert systems AND information science - $932^{6}$. Największą liczbę rekordów bibliograficznych, znalezionych według wyrażenia złożonego expert systems AND information science, zawierała baza SCOPUS (702 rekordy) ${ }^{7}$. Rekordy bibliograficzne wyszukano według słów kluczowych nadawanych przez autora dokumentu (Author keywords) oraz słów kluczowych indeksowanych w bazie (Indexed keywords). Do słów kluczowych należały wyrażenia: expert system, expert systems, information science, oraz wyrażenia złożone, zawierające wyrazy: expert, information, science, system, systems, np. expert knowledge, rule based system, intelligent systems. Na rysunku 1 przedstawiono liczbę publikacji zarejestrowanych w bazie SCOPUS w latach 1961-2011 ${ }^{8}$.

Największą liczbę rekordów bibliograficznych piśmiennictwa na temat systemów ekspertowych wyszukano w bazie INSPEC (48147 rekordów) ${ }^{9}$. Liczbę publikacji zarejestrowanych w bazie INSPEC w kolejnych latach przedstawia rysunek 2.

Liczbę publikacji dotyczących systemów ekspertowych i zarejestrowanych w bazie LISA ${ }^{10}$ w kolejnych przedziałach czasowych przedstawia rysunek 3. Zwrócono także uwagę na

${ }^{4}$ Baza Web Knowledge umożliwia przeszukanie baz: Arts \& Humanities Citation Index (1975-), Conference Proceeding Citation Index - Science (1990-), Conference Proceeding Citation Index - Social Science \& Humanities (1990-), Science Citation Index Expanded (1945-), Social Sciences Citation Index (1956-).

${ }^{5}$ Wyniki wyszukiwania dla: Topic=("expert systems") AND Topic=("information science") Timespan $=$ All Years. Databases $=$ SCI-EXPANDED, SSCI, A\&HCI, CPCI-S, CPCI-SSH.

${ }^{6}$ Należy pamiętać, że wśród wyszukanych rekordów część mogła się powtórzyć, zatem liczba zarejestrowanych dokumentów jest mniejsza.

7 Baza SCOPUS to wielodziedzinowa baza bibliograficzno-abstraktowa wydawnictwa Elsevier, w której wybrane artykuły posiadają linki do pełnego tekstu. Zasięg chronologiczny: od 1966 r. Obecnie zawiera $41 \mathrm{mln}$ abstraktów, ok. 18 tys. tytułów czasopism od przeszło 5 tys. wydawców, 3 mln materiałów konferencyjnych, $23 \mathrm{mln}$ patentów.

${ }^{8}$ Liczbę publikacji w bazie SCOPUS określono na podstawie badań przeprowadzonych w $04.2011 \mathrm{r}$.

${ }^{9}$ Baza INSPEC jest źródłem bibliograficznym w języku angielskim, zawierającym informacje nt. światowej literatury naukowej z dziedziny fizyki, elektroniki, elektrotechniki, technologii elektronowej, inżynierii (także inżynierii wiedzy), komunikacji, informatyki i teorii informacji. Materiał gromadzony w bazie przez Institute of Electrical Engineers obejmuje okres od $1969 \mathrm{r}$. W chwili obecnej baza zawiera około 7,3 mln opisów bibliograficznych.

${ }_{10}$ Baza LISA (ang. Library and Information Science Abstracts) jest podstawową bazą z zakresu bibliotekoznawstwa i informacji naukowej. Rejestruje streszczenia artykułów z ponad 440 czasopism fachowych, wydawanych w 20 językach w 68 krajach. Jest uzupełniana kwartalnie. Zasięg chronologiczny: od 1969 r. 
różną liczbę rekordów bibliograficznych wyszukanych za pomocą indeksów dostępnych w bazie (por. Tab. 2).

Rysunek 1. Liczba publikacji na temat systemów ekspertowych zarejestrowanych w bazie SCOPUS w przedziałach czasowych

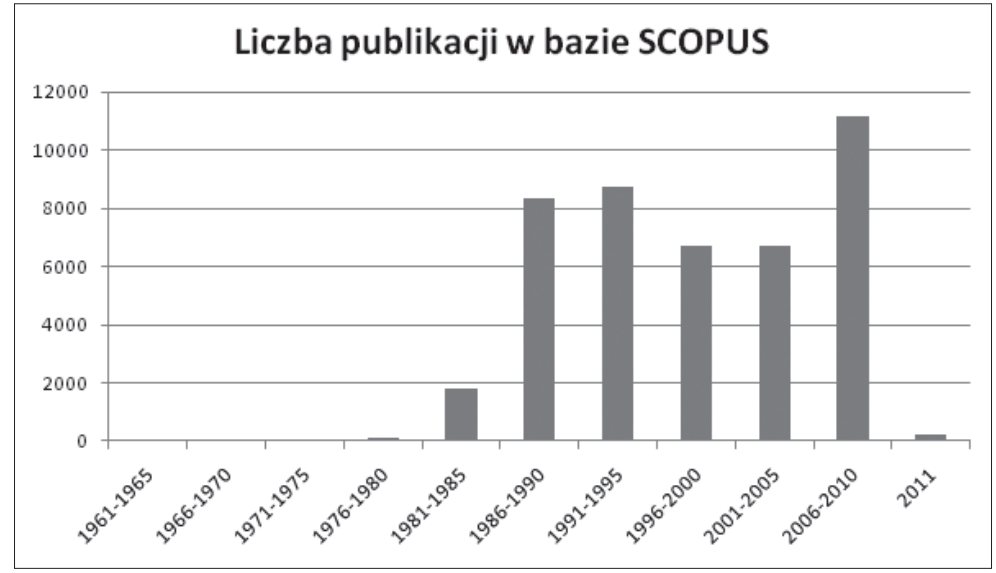

Rysunek 2. Liczba publikacji na temat systemów ekspertowych zarejestrowanych $\mathrm{w}$ bazie INSPEC $\mathrm{w}$ przedziałach czasowych

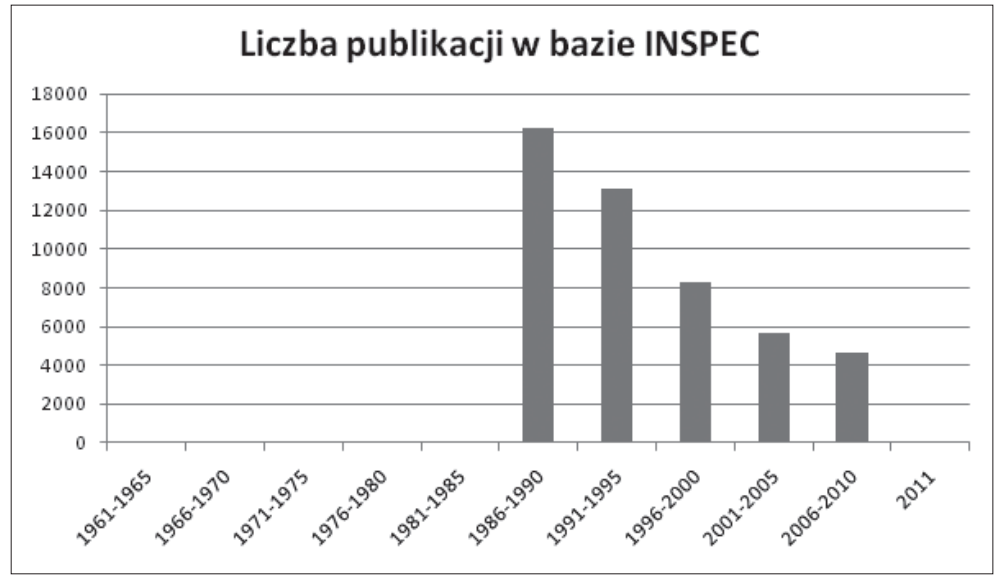

Tabela 2. Liczba rekordów bibliograficznych wyszukanych z wykorzystaniem dostępnych indeksów w bazie LISA

\begin{tabular}{|c|l|l|c|}
\hline Lp. & \multicolumn{1}{|c|}{ Nazwa indeksu } & $\begin{array}{c}\text { Instrukcja wyszukiwawcza/ } \\
\text { słowo kluczowe }\end{array}$ & $\begin{array}{c}\text { Liczba } \\
\text { wyszukanych } \\
\text { rekordów }\end{array}$ \\
\hline $\mathbf{1}$ & $\mathbf{2}$ & $\mathbf{3}$ & $\mathbf{4}$ \\
\hline 1 & Abstract & $\mathrm{AB}=($ expert systems $)$ & 807 \\
\hline 2 & Anywhere & expert systems & 1945 \\
\hline
\end{tabular}




\begin{tabular}{|c|l|l|c|}
\hline $\mathbf{1}$ & \multicolumn{1}{|c|}{$\mathbf{2}$} & \multicolumn{1}{c|}{$\mathbf{3}$} & $\mathbf{4}$ \\
\hline 3 & Classification & $\mathrm{CL}=$ (expert systems) & 0 \\
\hline 4 & Descriptors & $\mathrm{DE}=($ expert systems) & 1411 \\
\hline 5 & Features & $\mathrm{FE}=($ expert systems) & 0 \\
\hline 6 & Journal Name & $\mathrm{JN}=($ expert systems) & 430 \\
\hline 7 & Keywords & $\mathrm{KW}=($ expert systems) & 1795 \\
\hline 8 & Source & $\mathrm{SO}=($ expert systems $)$ & 430 \\
\hline 9 & Title & $\mathrm{TI}=($ expert systems $)$ & 294 \\
\hline
\end{tabular}

Rysunek 3. Liczba publikacji na temat systemów ekspertowych rejestrowanych w bazie LISA w przedziałach czasowych

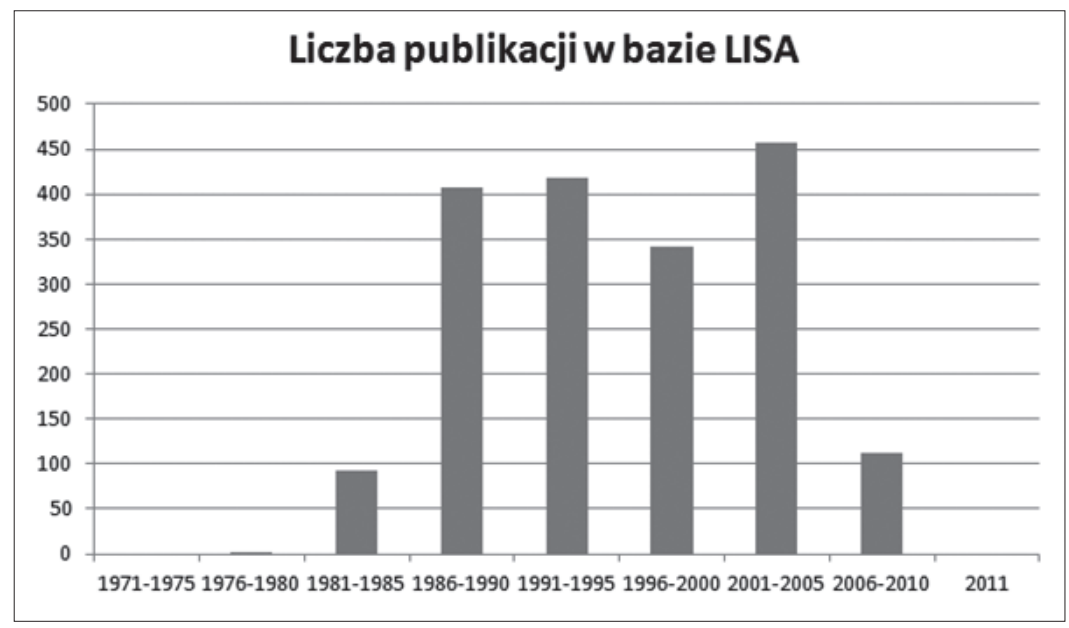

Rysunki 1 i 3 wyglądają podobnie, natomiast w bazie INSPEC (Rys. 2) publikacje pojawiły się później, od razu w dużej liczbie, a potem regularnie spadały. Zauważone różnice mogą wynikać z różnych zakresów tematycznych piśmiennictwa rejestrowanego w poszczególnych bazach, a także z faktu, że współcześnie systemy ekspertowe zostały wbudowane w szersze moduły aplikacyjne i do nich raczej, a nie do ogólnej klasy systemów ekspertowych, odnoszą się stosowane terminy indeksowe.

\section{Terminologia stosowana w bazach danych}

Ciekawych informacji o nazewnictwie zagadnień związanych z systemami ekspertowymi, omawianych w piśmiennictwie naukowym, dostarcza analiza słownictwa prezentowanego $\mathrm{w}$ tezaurusach stosowanych do indeksowania w bibliograficznych bazach danych. Terminy szersze, węższe i kojarzeniowe dla wybranych terminów wyszukiwawczych przedstawiono na przykładzie bazy INSPEC w tabeli 3.

W prezentowanym fragmencie tezaurusa INSPEC można zauważyć, że termin expert systems nie jest skojarzony $\mathrm{z}$ terminem information science. Terminy te łączy relacja 
współrzędności. Nadrzędnym deskryptorem wobec wymienionych terminów jest termin computer applications. Deskryptor knowledge based systems występuje jako termin nadrzędny do terminu expert systems, a deskryptor artificial intelligence jest $\mathrm{w}$ relacji kojarzeniowej z terminem expert systems i terminem nadrzędnym do terminu knowledge engineering. Wyraz knowledge występuje też w innych związkach frazeologicznych (knowledge acquisition, knowledge based systems, knowledge management, knowledge representation, knowledge verification), które pozostają w relacjach semantycznych z terminami wyszukiwawczymi expert systems i knowledge engineering. Szczegółowa analiza terminów w tezaurusie INSPEC mogłaby posłużyć do zbadania pola semantycznego różnych dyscyplin, zajmujących się problematyką systemów ekspertowych, co jednak wykracza poza ramy tego opracowania.

Tabela 3. Wykazy terminów szerszych, węższych i kojarzeniowych dla wybranych terminów wyszukiwawczych w bazie INSPEC

\begin{tabular}{|c|c|c|}
\hline Lp. & $\begin{array}{l}\text { Rodzaje terminów }{ }^{11} \text { (liczba powiąza- } \\
\text { nych terminów w bazie) }\end{array}$ & Odpowiedniki terminów w języku polskim ${ }^{12}$ \\
\hline 1 & 2 & 3 \\
\hline \multirow{4}{*}{1} & ST: expert systems (31 134) & systemy ekspertowe \\
\hline & $\begin{array}{l}\text { BT: computer applications (524) } \\
\text { knowledge based systems ( } 31187)\end{array}$ & $\begin{array}{l}\text { aplikacje (programy) komputerowe } \\
\text { systemy oparte na wiedzy }\end{array}$ \\
\hline & $\begin{array}{l}\text { NT: aerospace expert systems }(487) \\
\text { diagnostic expert systems }(3164) \\
\text { expert system shells }(653) \\
\text { intelligent design assistants }(2540) \\
\text { medical expert systems }(3680)\end{array}$ & $\begin{array}{l}\text { systemy ekspertowe w lotnictwie i kosmonautyce } \\
\text { diagnostyczne systemy ekspertowe } \\
\text { szkieletowe systemy ekspertowe } \\
\text { wspomaganie inteligentnego programowania } \\
\text { systemy ekspertowe w medycynie }\end{array}$ \\
\hline & $\begin{array}{l}\text { RT: artificial intelligence (18035) } \\
\text { cause-effect analysis (334) } \\
\text { decision support systems (21555) } \\
\text { explanation (2014) } \\
\text { group decision support systems (1710) } \\
\text { knowledge acquisition (12055) } \\
\text { possibility theory (1738) }\end{array}$ & $\begin{array}{l}\text { sztuczna inteligencja } \\
\text { analiza przyczynowo-skutkowa } \\
\text { systemy wspomagania decyzji } \\
\text { objaśnianie, wyjaśnienie }{ }^{13} \\
\text { grupowe (hybrydowe) systemy wspomagania } \\
\text { decyzji } \\
\text { tworzenie bazy wiedzy } \\
\text { teoria możliwości }\end{array}$ \\
\hline
\end{tabular}

${ }^{11}$ Uwzględniono następujące rodzaje terminów: ST (ang. Search Term) - termin wyszukiwawczy; BT (ang. Broader Terms) - terminy szersze; NT (ang. Narrower Terms) - terminy węższe; RT (ang. Related Terms) - terminy kojarzeniowe; UF (ang. Used For) - askryptory.

12 Do tłumaczenia terminów angielskich wykorzystano słownik Angielsko-polski słownik informacji naukowej i bibliotekoznawstwa (Tomaszczyk, 2009).

${ }^{13}$ Uczenie się na podstawie wyjaśnień (ang. explanation-based learning) i uczenie się na podstawie przykładów (ang. empirical learning) są dwiema, w dużym stopniu uzupełniającymi się metodami uczenia się maszyn (ang. machine learning) (Pazzani et al., 1991). 


\begin{tabular}{|c|c|c|}
\hline 1 & 2 & 3 \\
\hline \multirow{4}{*}{2} & ST: information science (2812) & informacja naukowa \\
\hline & BT: computer applications (524) & aplikacje (programy) komputerowe \\
\hline & $\begin{array}{l}\text { NT: document delivery (1328) } \\
\text { information analysis (2430) } \\
\text { information centers (1243) } \\
\text { information dissemination (3937) } \\
\text { information needs (3216) } \\
\text { information retrieval (34125) } \\
\text { information retrieval systems (10537) } \\
\text { information services (12498) } \\
\text { information storage (2008) } \\
\text { information use (1645) } \\
\text { RT: information industry (824) } \\
\text { information science education (1492) } \\
\text { language translation (5195) } \\
\text { libraries (3480) } \\
\text { microforms (686) } \\
\text { publishing (2828) } \\
\text { text editing (1803) }\end{array}$ & $\begin{array}{l}\text { dostarczanie dokumentów } \\
\text { analiza informacji } \\
\text { ośrodki informacji } \\
\text { rozpowszechnianie informacji } \\
\text { potrzeby informacyjne } \\
\text { wyszukiwanie informacji } \\
\text { systemy wyszukiwania informacji } \\
\text { usługi informacyjne } \\
\text { przechowywanie informacji } \\
\text { wykorzystanie informacji } \\
\text { przemysł informacyjny }{ }^{14} \\
\text { edukacja w zakresie nauki o informacji } \\
\text { tłumaczenia językowe } \\
\text { biblioteki } \\
\text { mikroformy } \\
\text { publikowanie } \\
\text { edytowanie tekstu }\end{array}$ \\
\hline & $\begin{array}{l}\text { UF: documentation } \\
\text { librarianship } \\
\text { library science }\end{array}$ & $\begin{array}{l}\text { dokumentacja } \\
\text { bibliotekarstwo } \\
\text { bibliotekoznawstwo }\end{array}$ \\
\hline \multirow{4}{*}{3} & ST: knowledge engineering (6463) & inżynieria wiedzy \\
\hline & BT: artificial intelligence (18 035) & sztuczna inteligencja \\
\hline & $\begin{array}{l}\text { NT: belief maintenance (2559) } \\
\text { explanation (2014) } \\
\text { inference mechanisms ( } 31350) \\
\text { knowledge acquisition (12055) } \\
\text { knowledge representation (16167) } \\
\text { knowledge verification (574) } \\
\text { truth maintenance (575) }\end{array}$ & $\begin{array}{l}\text { systemy przekonań } \\
\text { objaśnianie, wyjaśnienie } \\
\text { mechanizmy wnioskowania } \\
\text { pozyskiwanie wiedzy } \\
\text { reprezentacja wiedzy } \\
\text { weryfikacja wiedzy } \\
\text { system obsługi sieci przekonań }^{15}\end{array}$ \\
\hline & $\begin{array}{l}\text { RT: knowledge management (12125) } \\
\text { user modelling (4185) }\end{array}$ & $\begin{array}{l}\text { zrządzanie wiedzą } \\
\text { modelowanie użytkownika }\end{array}$ \\
\hline
\end{tabular}

\section{Analiza literatury przedmiotu}

W następnych częściach artykułu przedstawiono informacje dotyczące wyników wyszukiwania w bazie LISA. Na podstawie zebranych danych wyodrębniono kategorie tematyczne,

${ }^{14} \mathrm{~W}$ tezaurusie Eurovoc występują terminy kojarzeniowe (RT): przemysł informatyczny, przemysł środków komunikowania, przetwarzanie informacji (Eurovoc, 2011).

${ }^{15}$ System utrzymania sieci przekonań (ang. truth maintenance system, TMS) jest metodą reprezentacji wiedzy, sieci przekonań i reprezentujących ich zależności. Metoda jest stosowana w celu przywrócenia spójności systemów (Webster, 2011). 
przeprowadzono analizę ilościową rekordów bibliograficznych piśmiennictwa na temat systemów ekspertowych, zbadano źródła publikacji w wyszukanych rekordach.

\subsection{Kategorie tematyczne}

Pogłębioną analizę tematyki piśmiennictwa dotyczącego systemów ekspertowych wykorzystywanych w bibliotekarstwie i działalności informacyjnej przeprowadzono na wynikach wyszukiwania w bazie Library and Information Science Abstracts. Kryterium wyszukiwawczym były słowa kluczowe expert systems i information science połączone operatorem AND. W zależności od wyboru indeksu (Anywhere i Keywords) w wyniku wyszukiwania otrzymano odpowiednio: 140 i 70 rekordów bibliograficznych. Na podstawie analizy abstraktów wybranych rekordów bibliograficznych wyróżniono następujące grupy tematów:

(1) Bibliotekoznawstwo: biblioteki (biblioteka elektroniczna, biblioteki cyfrowe, biblioteki szkolne, szkolne centra informacji, biblioteki uniwersyteckie); technologia w bibliotece, innowacje technologiczne.

(2) Informacja naukowa: badania, bibliometria, etyka informacji, grupy dyskusyjne, informetria, produkty i ich charakterystyka (w tym czasopisma, systemy ekspertowe i bazy danych), teoria i praktyka, wyszukiwanie (także wyszukiwanie informacji online).

(3) Informacja naukowa i informatyka: architektura wiedzy (informacji), bazy danych (bazy danych online, wybór baz danych), eksploracja danych, Internet, modele poznawcze, systemy baz wiedzy, systemy wspomagania decyzji (proces wspomagania decyzji), sztuczna inteligencja, technologia informacyjna, wirtualna edukacja, World Wide Web, zarządzanie informacją, zarządzanie wiedzą (metodologia, metody, technologie do zarządzania wiedzą, środki, ocena, efektywność, przeglądy literatury).

(4) Informatyka: aplikacje (programy) komputerowe, automatyczna analiza tekstu (kognitywistyka, semiotyka), języki zapytań, wielowymiarowa baza danych baza OLAP (ang. OLAP cube).

(5) Systemy ekspertowe:

a. Definicja;

b. Elementy systemu ekspertowego: bazy wiedzy, silnik wnioskowania, interfejs użytkownika, moduł akwizycji wiedzy;

c. Rodzaje: hybrydowe systemy ekspertowe (pierwszej i drugiej generacji), sieci systemów ekspertowych z różnych dziedzin;

d. Prace badawcze: opis bibliograficzny, standard USBC (ang. Universal Standard Bibliographic Code); indeksowanie tekstów w bazie wiedzy z wykorzystaniem morfologiczno-syntaktycznej analizy języka (moduł MIDAS, ang. Module for the Identification of Analytics); systemy klasyfikacji w bazie wiedzy; badania w zakresie sztucznej inteligencji i systemów ekspertowych prowadzone przez grupę badaczy INFORSK w Umea w Szwecji; badania Lindy Smith w zakresie wyszukiwania informacji i automatyzacji bibliotek w University of Illinois Library School;

e. Przykłady: CATALYST, CIDA (ang. Company Information Database Adviser), GRANT, MAKLUM, PLEXUS, prototypowy system Zorana Ercegovaca do katalogowania map; 
f. Zastosowanie: bibliotekarstwo i informacja naukowa (administracja, dostarczanie dokumentów, katalogowanie, klasyfikacja, indeksowanie, planowanie, usługi informacyjne, wybór baz danych, wyszukiwanie informacji - także w systemach OPAC, zarządzanie wiedzą), informetria, informatyka, kształcenie zawodowe (systemy ekspertowe w programach nauczania), medycyna i diagnostyka medyczna, wspomaganie decyzji w analizie biznesowej i analizie konkurencyjności;

g. Artykuły przeglądowe na temat zastosowania sztucznej inteligencji i systemów ekspertowych w bibliotekarstwie, przeglądy literatury.

\subsection{Analiza ilościowa}

Wyszukane piśmiennictwo poddano analizie ilościowej w przekroju chronologicznym. Rekordy bibliograficzne publikacji na temat systemów ekspertowych stosowanych w bibliotekarstwie i działalności informacyjnej uporządkowano według daty wydania, otrzymując ich rozkład w poszczególnych latach. Uzyskane rezultaty przedstawia rysunek 4.

Rysunek 4. Liczba publikacji dotyczących systemów ekspertowych w bazie LISA według daty wydania

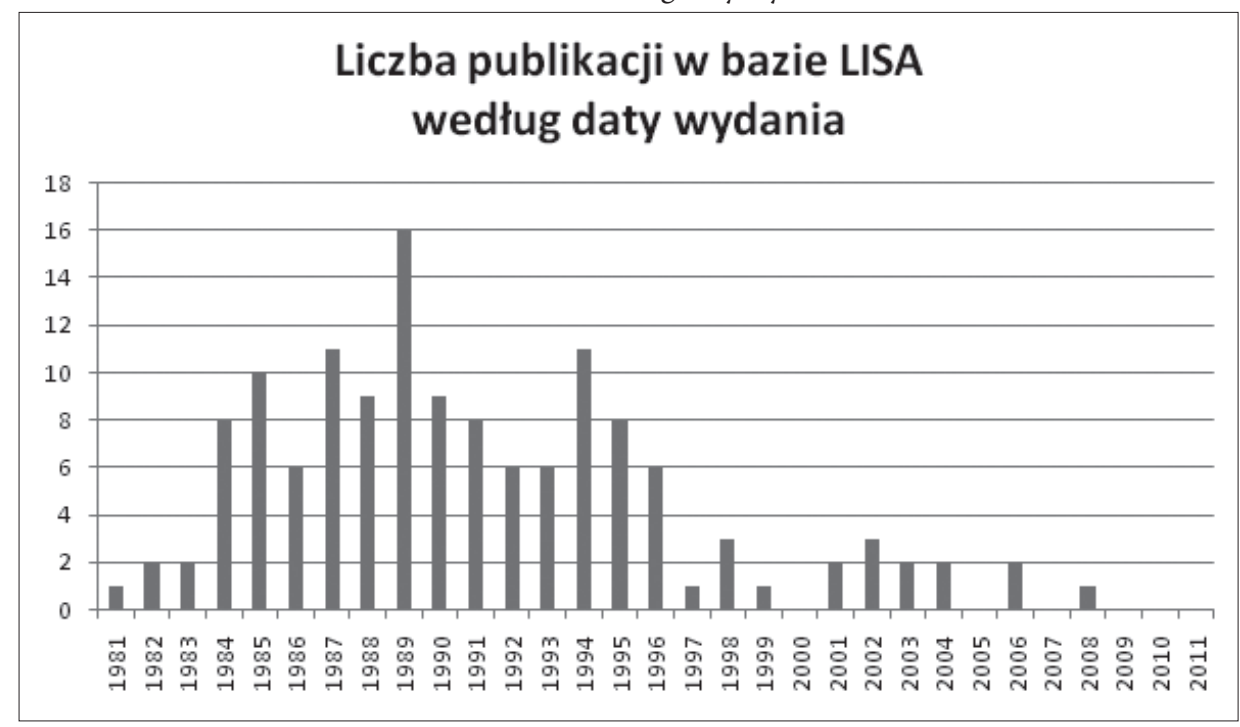

Najwięcej publikacji ukazało się w 1989 r. (16 ze 140 rekordów), najmniej - po 1 publikacji w latach 1981, 1997, 1999, 2008. W okresie od 1984 do 1996 r. liczba zarejestrowanych w LISA prac poświęconych systemom ekspertowym wahała się od 6 do 11 . W latach 2000, 2005, 2007 oraz 2009-2011 nie odnotowano żadnych wydań. Na rysunku 4 widać wyraźnie wygasanie zainteresowania systemami ekspertowymi.

\section{3. Źródta publikacji}

W wyszukanych rekordach bibliograficznych zbadano źródła publikacji. Autorzy ogłaszali swoje prace w czasopismach (119 ze 140 publikacji) oraz w materiałach konferencyjnych 
(21 ze 140 publikacji). Prace ukazały się w 53 czasopismach. Najwięcej artykułów opublikowano w periodykach: Journal of the American Society for Information Science (21 artykułów), Journal of Information Science (12 artykułów), Journal of the American Society for Information Science and Technology (8 artykułów), Information Processing and Management (7 artykułów) oraz Annual Review of Information Science and Technology i Canadian Journal of Information Science (po 5 artykułów). Ponieważ tytuły Journal of the American Society for Information Science i Journal of the American Society for Information Science and Technology odnoszą się do tego samego periodyku, który od 2001 r. ukazuje się pod drugim z nich, uzyskane dane jednoznacznie wskazują, że w tym właśnie czasopiśmie opublikowano najwięcej artykułów poświęconych systemom ekspertowym (łącznie 29). W 35 czasopismach ukazał się tylko jeden artykuł. Szczegółowe dane na temat liczby publikacji w poszczególnych czasopismach zamieszczono w tabeli 4.

Tabela 4. Liczba publikacji w bazie LISA według tytułów czasopism

\begin{tabular}{|c|c|c|c|}
\hline Lp. & Tytuł czasopisma/ISSN & $\begin{array}{c}\text { Liczba } \\
\text { artyku- } \\
\text { lów }\end{array}$ & $\begin{array}{l}\text { Rok publikacji arty- } \\
\text { kułu }\end{array}$ \\
\hline 1 & 2 & 3 & 4 \\
\hline 1 & Annual Review of Information Science and Technology --- & 5 & $\begin{array}{l}1984,1985,1991,1991 \\
1994\end{array}$ \\
\hline 2 & Argus ISSN 0315-9930 & 1 & 1985 \\
\hline 3 & Aslib Information ISSN 0305-0033 & 1 & 1988 \\
\hline 4 & Aslib Proceedings ISSN 0001-253X & 2 & 1984,1989 \\
\hline 5 & Audiovisual Librarian ISSN 0302-3451 & 1 & 1989 \\
\hline 6 & Australian Library Review ISSN 1034-8042 & 1 & 1990 \\
\hline 7 & Biblioteksbladet --- & 2 & 1985,1986 \\
\hline 8 & $\begin{array}{l}\text { Bulletin of the American Society for Information Science } \\
\text { ISSN 0095-4403 }\end{array}$ & 2 & 1986, 1990 \\
\hline 9 & $\begin{array}{l}\text { Canadian Journal of Information and Library Science } \\
\text { ISSN 1195-096X }\end{array}$ & 2 & 2003 \\
\hline 10 & Canadian Journal of Information Science ISSN 0380-9218 & 5 & $\begin{array}{l}1985,986,1986,1988 \\
1990\end{array}$ \\
\hline 11 & Cataloging and Classification Quarterly ISSN 0163-9374 & 1 & 1990 \\
\hline 12 & College and Research Libraries ISSN 0010-0870 & 1 & 1995 \\
\hline 13 & Computers in Libraries ISSN 1041-7915 & 1 & 1989 \\
\hline 14 & $\begin{array}{l}\text { DESIDOC Bulletin of Information Technology ISSN 0971- } \\
4383\end{array}$ & 2 & 1996, 1996 \\
\hline 15 & Education for Information ISSN 0167-8329 & 2 & 1985, 1991 \\
\hline 16 & Electronic Library ISSN 0264-0473 & 2 & 1989, 1996 \\
\hline 17 & Expert Systems ISSN 0266-4720 & 1 & 1993 \\
\hline 18 & Expert Systems for Information Management ISSN 0953-5551 & 3 & 1988, 1990, 1991 \\
\hline 19 & Information Processing and Management ISSN 0306-4573 & 7 & $\begin{array}{l}1987,1987,1987,1987 \\
1988,1990,1991\end{array}$ \\
\hline
\end{tabular}




\begin{tabular}{|c|c|c|c|}
\hline 1 & 2 & 3 & 4 \\
\hline 20 & Information Technology and Libraries ISSN 0730-9295 & 1 & 1989 \\
\hline 21 & International Classification ISSN 0340-0050 & 1 & 1989 \\
\hline 22 & $\begin{array}{l}\text { International Journal of Applied Expert Systems } \\
\text { ISSN 0969-9317 }\end{array}$ & 1 & 1993 \\
\hline 23 & Journal of Documentation ISSN 0022-0418 & 1 & 1987 \\
\hline 24 & $\begin{array}{l}\text { Journal of Education for Library and Information Science } \\
\text { ISSN } 0748-5786\end{array}$ & 3 & 1989, 1992, 1992 \\
\hline 25 & $\begin{array}{l}\text { Journal of the American Society for Information Science } \\
\text { ISSN 0002-8231 }\end{array}$ & 21 & $\begin{array}{l}\text { 1982, 1982, 1983, 1984, } \\
\text { 1985, 1986, 1988, 1989, } \\
\text { 1989, 1989, 1990, 1991, } \\
\text { 1991, 1991, 1992, 1992, } \\
\text { 1992, 1993, 1994, 1998, } \\
1999\end{array}$ \\
\hline 26 & $\begin{array}{l}\text { Journal of the American Society for Information Science and } \\
\text { Technology ISSN 1532-2882 }\end{array}$ & 8 & $\begin{array}{l}2002,2002,2003,2004 \\
2005,2005,2005,2008\end{array}$ \\
\hline 27 & $\begin{array}{l}\text { Journal of Information, Communication, and Library Science } \\
\text { ISSN 1024-1302 }\end{array}$ & 1 & 1996 \\
\hline 28 & Journal of Information and Image Management & 1 & 1986 \\
\hline 29 & Journal of Information and Management ISSN 0972-2467 & 1 & 2005 \\
\hline 30 & Journal of Information Science ISSN 0165-5515 & 12 & $\begin{array}{l}\text { 1984, 1984, 1987, 1989, } \\
1990,1991,1994,1994, \\
1994,1998,2001,2006\end{array}$ \\
\hline 31 & $\begin{array}{l}\text { Journal of Library and Information Science (USA/Taiwan) } \\
\text { ISSN 0363-3640 }\end{array}$ & 1 & 1994 \\
\hline 32 & $\begin{array}{l}\text { Journal of Librarianship and Information Science } \\
\text { ISSN 0961-0006 }\end{array}$ & 3 & $1994,1995,1996$ \\
\hline 33 & $\begin{array}{l}\text { Journal of the China Society for Scientific and Technical } \\
\text { Information ISSN 1000-0135 }\end{array}$ & 1 & 2006 \\
\hline 34 & Knowledge Organization ISSN 0943-7444 & 1 & 2004 \\
\hline 35 & Libri ISSN 0024-2667 & 1 & 1994 \\
\hline 36 & Library and Information Science Research ISSN 0740-8188 & 2 & 1988,1994 \\
\hline 37 & $\begin{array}{l}\text { Library Science with a Slant to Documentation } \\
\text { ISSN 0254-2553 }\end{array}$ & 1 & 1988 \\
\hline 38 & Library Software Review ISSN 0742-5759 & 1 & 1993 \\
\hline 39 & $\begin{array}{l}\text { Malaysian Journal of Library and Information Science } \\
\text { ISSN 1394-6234 }\end{array}$ & 3 & 1996, 1997, 2001 \\
\hline 40 & $\begin{array}{l}\text { Nauchno-Tekhnicheskaya Informatsiya. Series } 1 \\
\text { ISSN 0548-0019 }\end{array}$ & 1 & 1998 \\
\hline 41 & $\begin{array}{l}\text { Nauchno-Tekhnicheskaya Informatsiya. Series } 2 \\
\text { ISSN 0548-0027 }\end{array}$ & 1 & 2002 \\
\hline 42 & New Review of Applied Expert Systems ISSN 1361-0244 & 1 & 1995 \\
\hline 43 & Online Kensaku ISSN 0286-3200 & 1 & 1989 \\
\hline
\end{tabular}




\begin{tabular}{|c|l|c|l|}
\hline 1 & \multicolumn{1}{|c|}{2} & \multicolumn{1}{|c|}{$\mathbf{1}$} & \multicolumn{1}{|c|}{$\mathbf{1}$} \\
\hline 44 & Perspectives in Information Management ISSN 0960-6513 & 1 & 1993 \\
\hline 45 & Program ISSN 0033-0337 & 1 & 1988 \\
\hline 46 & RQ ISSN 0033-7072 & 1 & 1995 \\
\hline 47 & Scire ISSN 1135-3716 & 1 & 1995 \\
\hline 48 & Science and Technology Libraries --- & 1 & 1987 \\
\hline 49 & $\begin{array}{l}\text { South African Journal of Library and Information Science } \\
\text { ISSN 0256-8861 }\end{array}$ & 1 & 1994 \\
\hline 50 & SRELS Journal of Information Management ISSN 0972-2467 & 1 & 2005 \\
\hline 51 & Synopsis ISSN 0332-656X & 1 & 1995 \\
\hline 52 & Technicka Knihovna --- & 1 & 1989 \\
\hline 53 & I'93 Casopis ISSN 0862-9382 & 1 & 1993 \\
\hline
\end{tabular}

\section{Przykłady zastosowań systemów ekspertowych}

W tej części artykułu przedmiotem rozważań są wybrane systemy ekspertowe ilustrujące różne obszary wykorzystywania tego typu narzędzi w działalności bibliotecznej i informacyjnej. Omówiono kolejno: systemy wspomagające stosowanie standardów bibliotecznych i bibliograficznych, systemy wspomagające wyszukiwanie online, systemy do wizualizacji informacji, systemy wykorzystujące technologię semantyczną oraz inne przykłady.

\subsection{Systemy wspomagajace stosowanie standardów bibliotecznych i bibliograficznych}

Istnieje wiele potencjalnych zastosowań sztucznej inteligencji i systemów ekspertowych w bibliotekach. W latach 1982-1983 w Exeter University w Wielkiej Brytanii opracowano dwa projekty systemów ekspertowych. Głównym zadaniem tych systemów było wybranie tzw. punktów dostępu i głównych elementów identyfikacji dokumentów, a następnie dodanie opisów. Jeden z tych systemów - ESSCAPE, był stosowany w procesie katalogowania dokumentów w celu uzyskania poprawnych rekordów bibliograficznych, zgodnych z zasadami AACR2 (ang. Anglo-American Cataloging Rules). Obecnie systemy ekspertowe do katalogowania mogą być wykorzystane w celu uzyskania poprawnych rekordów bibliograficznych. Ich wykorzystanie może być przydatne w nietradycyjnych środowiskach, gdzie opisy dokumentów tworzą nieprofesjonaliści; w normalnych warunkach pracy biblioteki, takie systemy wydają się być mniej znaczące. Katalogowanie z wykorzystaniem systemów ekspertowych może jednak być pomocne również dla specjalistów, ma bowiem wartość edukacyjną i jest formą gromadzenia wiedzy (Hjerppe \& Olander, 1989).

System ekspercki MAKLUM, wspomagający pracę bibliotekarzy i specjalistów z zakresu informacji naukowej, miał na celu udzielenie odpowiedzi na pytania ogólne, dotyczące wyposażenia biblioteki, usług, przepisów, członkostwa, lokalizacji itp. System został opracowany dla Biblioteki Głównej Uniwersytetu Malajskiego przy wykorzystaniu systemu szkieletowego CRYSTAL (Zainib \& Zaid, 1996). 
Projekt standardu opisu bibliograficznego USBC (ang. Universal Standard Bibliographic Code), w połączeniu z projektem DOCMATCH, przewidywał tworzenie dużych bibliograficznych baz danych, integrujących rekordy z różnych baz oraz opracowanie systemu ekspertowego do wyszukiwania duplikatów rekordów. Jak stwierdzono w raporcie z realizacji projektu, przygotowanym przez pracowników Wydziału Informatyki Uniwersytetu w Bradford w Wielkiej Brytanii, USBC nigdy nie osiągnął statusu standardu (Ayres et al., 1996), toteż opracowany system ekspertowy do wykrywania duplikatów rekordów opracowanych w tym standardzie ma niewielka wartość użytkową

\subsection{Systemy wspomagajace wyszukiwanie online}

W połowie lat 80 . XX w. systemy ekspertowe nowej generacji wykorzystywano do wyszukiwania w bazach danych i gromadzenia wyszukanej informacji. W przypadku baz danych, w których sieci semantyczne były używane jako metody reprezentacji wiedzy, systemy te wspomagały wyszukiwanie informacji z tekstów publikacji naukowych. Proces wyszukiwania informacji analizowano na przykładzie baz danych z zakresu nauk technicznych (Nowak \& Szablowski, 1984).

W przeglądowej pracy Donalda T. Hawkinsa omówiono systemy ułatwiające tworzenie strategii wyszukiwania i formułowanie instrukcji wyszukiwawczych: Answerman, ARGON, CANSEARCH, CITE (ang. Computerized Information Transfer in English), CONIT (ang. Connector for Networked Information Transfer), ekspertowy system konsultacyjny P. Shovala, IIDA (ang. Individualized Instruction for Data Access), IR-NLI (ang. Information Retrieval - Natural Language Interface), IT (ang. Information Transfer), ORA, PLEXUS, Ready Reference Thesaurus System, RUBRIC (Hawkins, 1988). Zwrócono uwagę, że dotychczasowe działania zmierzające do ułatwienia wyszukiwania online skupiały się przede wszystkim na operacjach mechanicznych, takich jak połączenie z siecią komputerową, przekazanie hasła (ang. password), wybór baz danych, wyświetlanie wyników czy polecenie wydruku wyników. Uproszczenie procesu wyszukiwania informacji powinno polegać na wspomaganiu operacji intelektualnych, związanych z określeniem tematu wyszukiwania, tworzeniem instrukcji i strategii wyszukiwawczej, interpretacją i oceną wyników wyszukiwania. Aby system ekspertowy mógł realizować tego rodzaju zadania należy wyposażyć go w metody i techniki sztucznej inteligencji (Sosińska-Kalata, 1990).

Ze względu na szybki wzrost liczby baz danych online i ich dostawców, wybór odpowiedniej bazy danych stawał się coraz bardziej skomplikowany, nie tylko dla użytkowników końcowych, ale również dla specjalistów informacji. Projekt systemu eksperckiego o nazwie ONLINE-EXPERT miał ułatwić to zadanie. System został zbudowany po zgromadzeniu wiedzy pozyskanej od ekspertów oraz zawartej w drukowanych dokumentach, w których użytkownicy mogli uzyskać porady na temat wyboru odpowiednich baz danych. Aby udoskonalić bazę wiedzy, zastosowano analizę wielokryterialnej decyzji (AHP, ang. Analytical Hierarchy Process). Technikę AHP wykorzystano do budowy modelu podejmowania decyzji, a w ramach systemu ekspertowego przewidziano ranking baz danych i komputerów w kolejności wybranych preferencji (Zahir \& Chang, 1992).

Prototypowy system CIDA (ang. Company Information Database Adviser) został zaprojektowany jako system wspierający użytkowników wyszukiwarki online. Wspomagał wybór informacji z dostępnych online baz danych o brytyjskich przedsiębiorstwach, w tym: 
podstawowych danych, informacji finansowych, informacji dotyczących własności, przejęć i fuzji, aktualnych wiadomości, szczegółowych profili fuzji. Był zalecany zarówno dla użytkowników krajowych jak i zagranicznych (Tseng et al., 1995).

\subsection{Systemy do wizualizacji informacji}

Algorytm analizy cytowań zaproponowany przez Eugene’a Garfielda we współpracy z Irving Sher w 1960 r., został rozwinięty w oprogramowaniu HistCite autorstwa Alexandra Pudovkina. Oprogramowanie obejmuje system ekspercki do wykrywania błędów redakcyjnych lub zmian w cytowaniach. Nowe rozwiązania w zakresie skalowania wielowymiarowego (MDS, ang. multidimensional scaling) pozwalają na wizualizację wzorców cytowań w różnym czasie, a także na ich animację (Leydesdorff, 2010). Słowa z tytułów prac, nazwiska współtwórców i nazwy czasopism oraz cytowania są elementami metody w przykładowej animacji opisu prac Eugene’a Garfielda (por. Rys. 5, 6 i 7) (Leydesdorff, b.d.).

Rysunek. 5. Widok strony przykładowej animacji wybranych elementów opisu prac Eugene Garfielda z okresu 1950-1955.

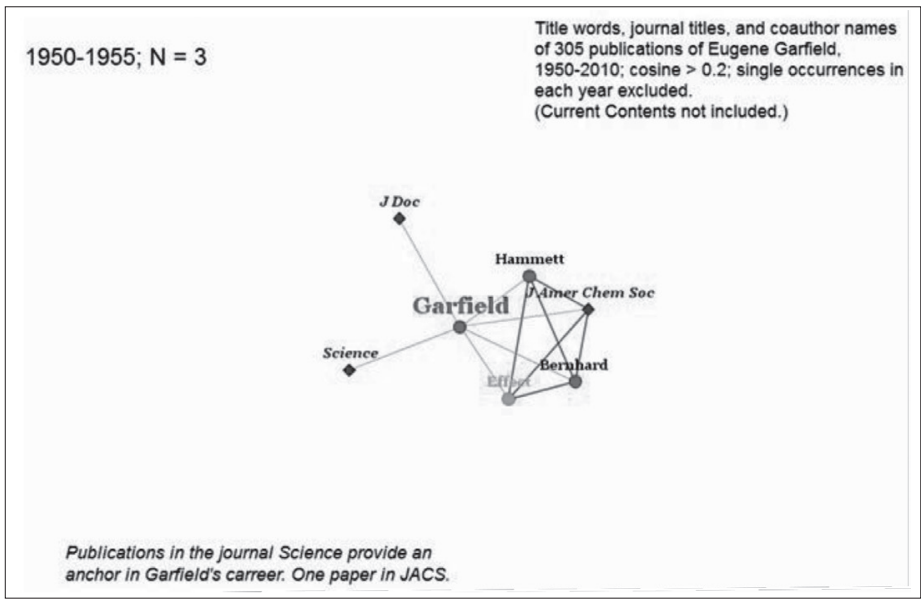

Źródło: Leydesdorff, b.d.

Program HistCite umożliwia generowanie i wizualizację powiązań między dokumentami (elementami opisów dokumentów) i autorami na podstawie danych pobranych z bazy Web of Science lub innych baz dostępnych na platformie Web of Knowledge i zapisanych w pliku tekstowym. Program tworzy indeks cytowań dla każdego określonego zestawu opisów dokumentów pobranych z Web of Science, a następnie generuje wykresy sieci cytowań poszczególnych publikacji, oznaczanych numerami. W dalszej kolejności są realizowane funkcjonalności: eksport danych w formacie CSV, pozwalający na dalsze przetwarzanie danych w arkuszu kalkulacyjnym oraz programach do analizy sieci społecznych; eksport danych $\mathrm{w}$ formacie HTML, pozwalający na prezentowanie wyników analiz oraz generowanie macierzy cytowań do dalszego przetwarzania w innych programach (Klincewicz et al., 2012). W programie zastosowano trzy modele identyfikacji cytowań w sieci (metody przypisywania wagi): NPPC (ang. Node Pair Projection Count), SPLC (ang. Search Path Link Count) i SPNP (ang. Search Path Node Pair). Korzystanie z analizy tzw. ścieżki głównej 
pozwala wyznaczyć środek zmian ewolucyjnych między kolejnymi dokumentami. Badania nad tą metodą wykazały, że jest możliwe wzbogacenie oprogramowania algorytmami z analizy sieci społecznych i teorii informacji, które wykraczają poza rekonstrukcję wiedzy historycznej (Lucio-Arias \& Leydesdorff, 2008).

Rysunek. 6. Widok strony przykładowej animacji wybranych elementów opisu prac Eugene Garfielda z okresu 1970-1975.

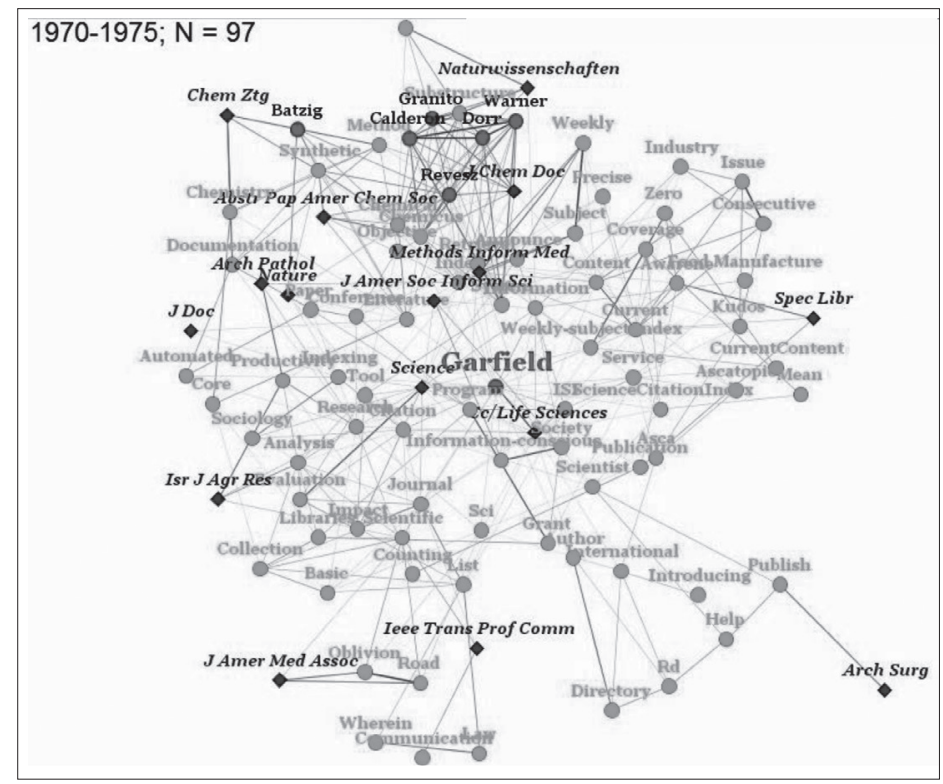

Źródło: Leydesdorff, b.d.

Rysunek. 7. Widok strony przykładowej animacji wybranych elementów opisu prac Eugene Garfielda z okresu 2005-2010.

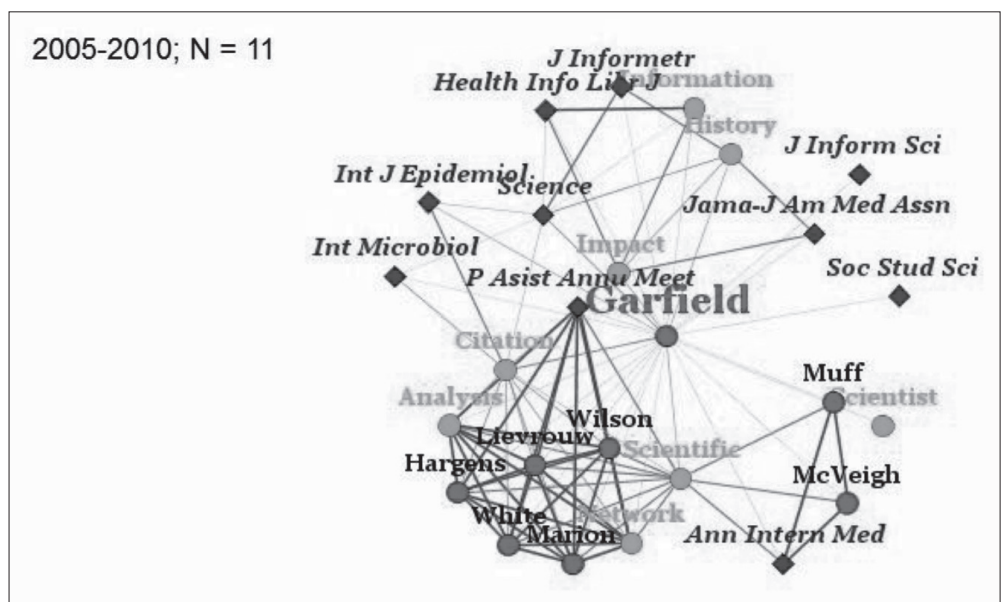

Źródło: Leydesdorff, b.d. 
Prototypowy system VIBE (ang. Visual Information Browsing Environment) powstał w Molde College w Norwegii we współpracy z naukowcami z University of Pittsburgh. Umożliwia użytkownikom ocenę wybranych dokumentów z zestawu, który jest graficznie reprezentowany w postaci geometrycznych ikon na ekranie. Metoda adaptacyjnej wizualizacji danych (ang. adaptive visualization) jest nowym podejściem, wykorzystującym modelowanie użytkownika i wizualizację informacji. System VIBE wykorzystuje tzw. punkty odniesienia (POI, ang. Point of Interest), oparte na wizualizacji. Wyświetla punkty, które reprezentują określone pojęcia lub słowa kluczowe i „rozmieszcza” je na ekranie według wskaźników podobieństwa do POI. Następnie tworzy tzw. schematy adaptacyjne (radialne, hemisferyczne, równoległe). Każdy z tych schematów zawiera dwie kategorie danych: model, składający się z zestawu słów kluczowych zebranych podczas interakcji użytkownika z systemem, oraz zapytań użytkownika wybranych za pomocą opcji dostępnych na ekranie. Użytkownik ma możliwość wyboru i zaznaczenia na ekranie odpowiednich słów kluczowych, a następnie przejścia do przypisanym im dokumentom. Program umożliwia także wyświetlenie dokumentów relewantnych i nierelewantnych (Ahn i Brusilovsky, 2010).

System Adaptive VIBE rozszerza możliwości systemu VIBE i może być wykorzystany do wyszukiwania w sieci Internet. Jest rozszerzoną wersją algorytmu opartego na wizualizacji przestrzennej, zaprojektowaną jako moduł interakcji użytkownika dla spersonalizowanego systemu wyszukiwania. Program umożliwia wyszukiwanie dostosowywane do każdego, indywidualnego użytkownika, uwzględnia jego dynamicznie zmieniające się zapytania, różne konteksty oraz ciągłą poprawę jakości wyników wyszukiwania. Wspiera także użytkownika w aktywnym wyszukiwaniu przez odkrywanie przestrzeni informacyjnej i uczenie się nowych faktów. Na podstawie badań użytkowników stwierdzono, że modelowanie użytkownika i technologia wizualizacji przestrzennej wzajemnie się uzupełniają, zwiększając poziom wsparcia dla użytkowników (Ahn \& Brusilovsky, 2009).

\subsection{Systemy wykorzystujące technologię semantycznq}

Firma Expert System SA jest dostawcą oprogramowania sieci semantycznej COGITO, które analizuje, klasyfikuje i interpretuje teksty (Expert..., 2011). Oprogramowanie pozwala odkryć i poznać połączenia w zestawach danych zawartych w: plikach, wiadomościach e-mail, artykułach, raportach, stronach internetowych. Do komunikowania się z systemem jest używany język naturalny. Technologia semantyczna (ang. semantic technology) umożliwia automatyczne rozumienie słów, zdań, akapitów i całych dokumentów. Szkieletowa sieć semantyczna jest podstawą dla ekstrakcji i kategoryzacji wiedzy, tworzenia domen, taksonomii i ontologii. Poniżej przedstawiono ideę działania oprogramowania COGITO (por. Rys. 7).

\subsection{Inne przyktady}

System do diagnostyki medycznej MatheMEDics, zawierający moduł EasyDiagnosis, umożliwia diagnozowanie chorób na podstawie grup objawów, do których należą: bóle głowy, brzucha, dolnej części pleców, bóle w klatce piersiowej. Program szacuje prawdopodobieństwo wystąpienia chorób lub stanów na podstawie wewnętrznej logiki i odpowiedzi na pytania. Na rysunku 8 przedstawiono fragment modułu zawierającego pytania i możliwe odpowiedzi w diagnostyce osteoporozy. 
Moduł Autodiagnoza jest częścią platformy informacyjnej dla pacjentów, zawierającej informacje o chorobach, badaniach, lekach, szpitalach i placówkach medycznych. Wyświetla listę objawów, które mogą występować we wskazanym obszarze (por. Rys. 9). Po wybraniu objawów użytkownik otrzymuje listę powiązanych dolegliwości, w których występują wskazane objawy. Serwis ma charakter wyłącznie informacyjno-edukacyjny, jego celem jest polepszenie, a nie zastąpienie, kontaktu między użytkownikiem a lekarzem (Medonet.pl, 2011).

Rysunek 8. Idea działania oprogramowania COGITO.

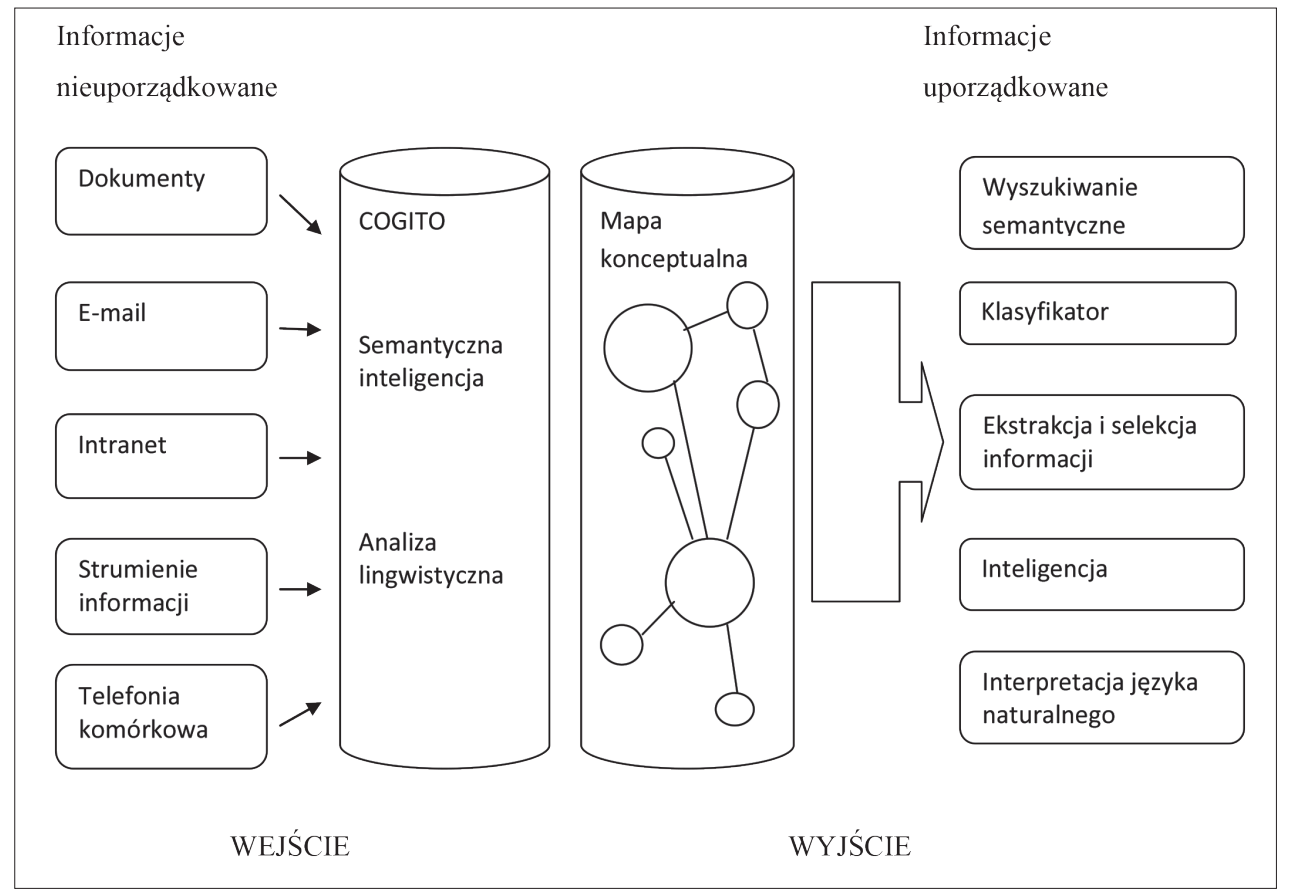

Źródło: Expert System Business Information, 2011.

Systemy ekspertowe są stosowane w sektorze rolnym, np. do diagnozowania maszyn i urządzeń rolniczych. Produkcja rolna wymaga gromadzenia i integracji wiedzy i informacji z różnych źródeł. W celu utrzymania konkurencyjności rolnik często korzysta z wiedzy specjalistów i doradców rolnych, poszukuje informacji przed podjęciem decyzji. Niestety, pomoc specjalistów nie zawsze jest możliwa wtedy, gdy rolnik jej potrzebuje. Aby rozwiązać ten problem, zaprojektowano systemy ekspertowe gromadzące wiedzę niezbędną w sektorze rolnym. Systemy wspomagania decyzji w zakresie optymalizacji wykorzystania zasobów i maksymalizacji produkcji żywności opracowano w Central Laboratory for Agricultural Expert Systems w Kairze (CLAES, 2011). Są to systemy ułatwiające podjęcie decyzji dotyczących uprawy roślin, ich przygotowania, nawadniania, nawożenia, diagnostyki i leczenia. Przykładowym systemem identyfikującym odmiany upraw jest Barley Expert System (por. Rys. 10). 
Rysunek 9. Widok strony modułu zawierającego pytania i możliwe odpowiedzi w diagnostyce osteoporozy.

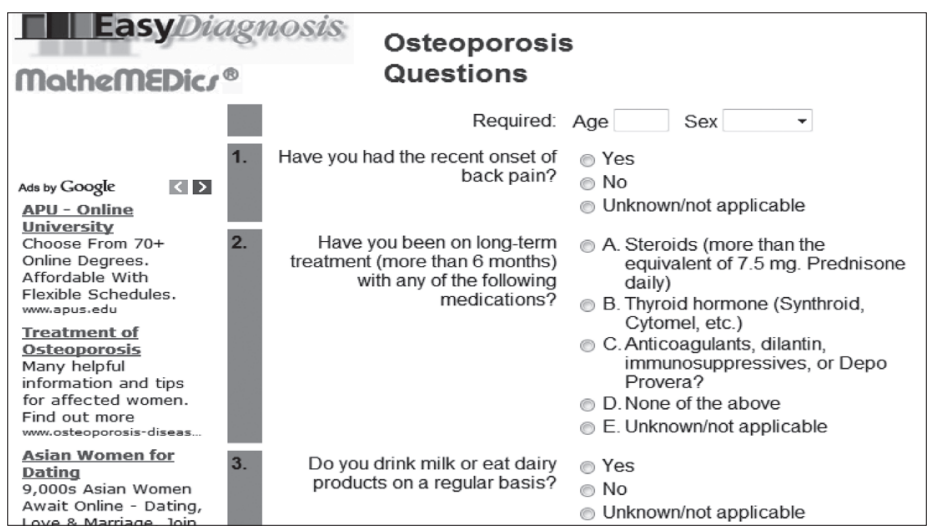

Żródło: MatheMEDics ${ }^{\oplus}$ expert online health software, 2011.

Rysunek 10. Widok strony modułu Autodiagnoza.

\begin{tabular}{|c|c|c|c|}
\hline \multicolumn{4}{|c|}{ Autodiagnoza } \\
\hline Postać: & & Wskaż interesujący Cię obszar ciała & Ważna informacja: \\
\hline \multirow{6}{*}{$\begin{array}{l}\text { kobieta } \\
\text { mężczyzna } \\
\text { dziecko }\end{array}$} & & $\begin{array}{l}\text { na ilustracji lub wybierz go z listy } \\
\text { poniżej. Przejdź dalej - otrzymasz } \\
\text { listę objawów, a w nastepnym kroku } \\
\text {-listę dolegliwośc ze wskazanymi } \\
\text { przez Ciebie objawami. }\end{array}$ & \multirow{2}{*}{$\begin{array}{l}\text { Po kliknięciu przycisku "Dalej", moduł } \\
\text { autodiagnozy wyświetti listę objawów, } \\
\text { które mogą występować we } \\
\text { wskazanym przez Ciebie obszarze, Po } \\
\text { wybraniu interesujacych Cię objawów } \\
\text { ottzymasz liste dolegliwości, którym } \\
\text { mogą towarzyszyć. Uwaga! Moduł ma } \\
\text { na celu polepszenie, a nie zastapienie, } \\
\text { kontaktu pomiędzy Użytkownikiem } \\
\text { serwisu a jego lekarzem. }\end{array}$} \\
\hline & & $\begin{array}{l}\text { Głowa, szyja, twarz } \\
\text { Oczy } \\
\text { Ucho, nos, usta, gardło } \\
\text { Klatka piersiowa }\end{array}$ & \\
\hline & & Brzuch i miednica & DALEJ \\
\hline & & $\begin{array}{l}\text { Bark, ramie, tokieć, } \\
\text { przedramię, ręka }\end{array}$ & \\
\hline & 4 & Uda, kolano, łydka i stopa & \\
\hline & Przód Tyl & Ogólnie & \\
\hline
\end{tabular}

Żródło: Medonet.pl, 2011.

Rysunek 11. Widok strony systemu Barley Expert System.

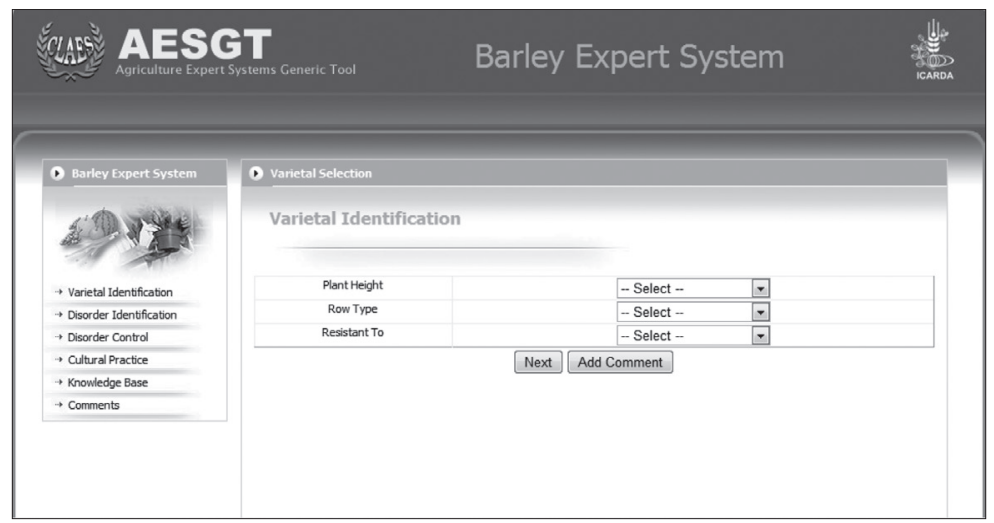

Żródło: CLAES, 2011. 


\section{Podsumowanie i wnioski}

Systemy ekspertowe są stosowane w wielu dziedzinach wiedzy: bioinformatyce (m.in. do analizy sekwencji biologicznych), diagnostyce, informetrii, informatyce, medycynie, rolnictwie, ekonomii. Systemy te wspierają procesy informacyjne: gromadzenie, przechowywanie i opracowanie informacji (tworzenie charakterystyki wyszukiwawczej dokumentu), wyszukiwanie informacji (tworzenie kwerend, pytania w języku naturalnym), przekazywanie i wdrażanie informacji. Wspomagają pracę bibliotekarzy i specjalistów z zakresu informacji naukowej, są stosowane do udzielania informacji użytkownikom bibliotek, wyszukiwania w Internecie, katalogowania i klasyfikacji, zarządzania biblioteką. Większość tych systemów jest jednak nadal w fazie eksperymentalnej.

Motywacją do tworzenia systemów ekspertowych był i jest trudny i kosztowny dostęp do eksperta. Systemy ekspertowe pracują znacznie szybciej, w działaniach rutynowych są bardziej niezawodne niż ludzie, a automatyczne wspomaganie obsługi jakiegoś urządzenia technicznego jest często jedynym, ekonomicznie uzasadnionym rozwiązaniem. Do ewentualnych korzyści związanych z zastosowaniem tych systemów należą:

(1) Zwolnienie ekspertów z rutynowych zadań na rzecz działań kreatywnych i wymagających zaangażowania.

(2) Gromadzenie wiedzy i kompetencji wielu ekspertów, co przyczynia się do rozwoju systemu, może pomóc w doskonaleniu procedur i utrzymaniu ich spójności.

(3) Zachowanie, opracowanie i rozpowszechniane wiedzy. Wiedza i doświadczenie osób, a także nakłady finansowe przeznaczone na ich szkolenia, mogą zostać utracone w przypadku opuszczenia firmy. Systemy ekspertowe stanowią sposób na zachowanie tej wiedzy, dostępnej w tym samym czasie dla wielu osób.

(4) Dostępność wiedzy eksperckiej. Systemy ekspertowe umożliwiają korzystanie z wiedzy eksperckiej przez 24 godziny na dobę, bez konieczności obecności eksperta.

(5) Możliwość szkoleń. Systemy ekspertowe mogą być wykorzystane do przeprowadzania szkoleń, rozwiązywania problemów, treningów sytuacyjnych. Szkolenia mogą obejmować wszystkich pracowników firmy lub indywidualne osoby, w godzinach dostosowanych do wymagań pracownika.

(6) Ustandaryzowane podejście do rozwiązywania problemów. Systemy ekspertowe mogą zapewnić standardowe podejście do rozwiązywania problemów.

(7) Krytyczna ocena rozwiązania problemu. Rozwój systemów ekspertowych umożliwia ekspertom krytyczną ocenę i poprawę rozwiązania problemu.

(8) Poprawa wydajności pracy. Eksploatacja systemów ekspertowych może pomóc mniej doświadczonym pracownikom osiągnąć lepsze wyniki w pracy, a w końcu nawet osiągnąć status eksperta.

(9) Szybkie rozwiązywanie problemów. W wielu sytuacjach systemy ekspertowe mogą rozwiązywać problemy znacznie szybciej niż ludzie-eksperci.

(10) Oszczędność i zwiększenie zysków. Systemy ekspertowe pozwalają na zaoszczędzenie dużych nakładów finansowych, co przyczynia się do zwiększenie zysków firmy (Singh et al., 1996).

Pierwsze, użyteczne w praktyce systemy doradcze, m.in. Dendral, Macsyma i Hearsay, powstały w drugiej połowie lat 60. (Michalik, 2011). W latach 1981-1990 wzrosła liczba praktycznie stosowanych systemów ekspertowych. Od lat 90. są tworzone duże 
systemy - budowane przez korporacje na własny użytek lub w celach komercyjnych i małe szybkie systemy z bazą wiedzy (od 50 do 200 reguł wnioskowania). W tym okresie wzrosła także liczba publikacji na temat systemów ekspertowych, co potwierdzają wyniki wyszukiwania w bazach LISA, INSPEC i SCOPUS (w tej ostatniej najwięcej publikacji zarejestrowano w latach 2006-2010).

W XXI w. badania nad systemami ekspertowymi koncentrują się wokół pozyskiwania i parametryzacji wiedzy (mapy tematów, wiedzy, umiejętności, macierze wiedzy i kompetencji), reprezentacji wiedzy w hybrydowych systemach wieloagentowych (Sieć Semantyczna, społeczności agentów, systemy wieloagentowe), a badania nad przetwarzaniem wiedzy w systemach baz wiedzy są częścią obszaru badań współczesnej inżynierii wiedzy.

Analiza ilościowa literatury przedmiotu wykazała spadek piśmiennictwa poświęconego systemom ekspertowym, co może wynikać z faktu, że coraz częściej systemy te są integralną częścią specjalistycznych modułów aplikacyjnych. W literaturze badawczej uwaga częściej skupiona jest więc na zastosowaniach technologii inteligentnej do rozwiązania określonych, dobrze zdefiniowanych zadań, niż na systemach ekspertowych jako ogólnej klasie systemów inteligentnych. W wyniku analizy ilościowej piśmiennictwa na temat systemów ekspertowych, które wyszukano w bazie LISA, rejestrującej publikacje z zakresu bibliotekoznawstwa i informacji naukowej, stwierdzono, że najwięcej prac na ten temat ukazało się w $1989 \mathrm{r}$. Nieco inny obraz zainteresowania problematyką tego typu systemów przedstawiają wyniki wyszukiwania w bazach INSPEC i SCOPUS, obejmujących piśmiennictwo z szeroko rozumianej nauki o informacji i innych dziedzin wiedzy zajmujących się zastosowaniami technologii komputerowych. W bazie INSPEC najwięcej publikacji odnotowano w latach 1986-1990, w bazie SCOPUS natomiast - w 2006-2010. Baza SCOPUS zawierała także największą liczbę rekordów bibliograficznych znalezionych według wyrażenia złożonego expert systems AND information science. Wyniki wyszukiwania w bazach LISA i INSPEC generalnie potwierdzają, że liczba publikacji na temat systemów ekspertowych wykazuje tendencję spadkową. Zastanawiająco duża liczba publikacji o tych systemach zarejestrowanych w bazie SCOPUS w okresie 2006-2010 wymaga dalszej analizy i weryfikacji w następnych latach, których już omawiane tu badanie nie obejmowało.

Systemy ekspertowe znajdują się w obszarze zainteresowań przede wszystkim specjalistów zajmujących się inżynierią (w tym inżynierią wiedzy), informatyką i teorią informacji. Od końca lat 80 . XX w. do połowy pierwszej dekady XXI w. wzbudzały natomiast szczególne zainteresowanie wśród bibliotekoznawców i informatologów.

Analiza piśmiennictwa poświęconego zastosowaniom systemów ekspertowych w działalności bibliotecznej i informacyjnej pozwala stwierdzić, że zyskały one opinię narzędzi pomocnych w efektywnym zarządzaniu informacją. Zwraca się jednak uwagę na fakt, że chociaż bibliotekarze i specjaliści informacji naukowej mogą przyczynić się do rozwoju systemów ekspertowych, to ich brak doświadczenia w programowaniu ogranicza możliwości projektowania takich systemów. Istnieje jednak zapotrzebowanie na takich specjalistów, którzy będą potrafili właściwie wspierać tworzenie systemów ekspertowych przeznaczonych do realizacji zadań w zakresie działalności bibliotecznej i informacyjnej (Morris \& O’Neill, 1990).

Możliwości wykorzystania systemów ekspertowych w bibliotece i nauce są duże. Należy jednak zauważyć, że ich zastosowanie jest ograniczone do dobrze określonych zadań, a ich przydatność w bibliotece zależy w dużym stopniu od sprawności sprzętu i oprogramowania. 
Oczekuje się, że systemy te znajdą zastosowanie w bibliotekach specjalistycznych, w zakresie gromadzenia i kodyfikacji wiedzy w wybranych obszarach specjalizacji. Na użyteczność systemów ekspertowych w bibliotekach i systemach informacyjnych wpływ ma też moc i wydajność wykorzystywanego w nich sprzętu i oprogramowania. Aby zaoferować swoim klientom usługi z wykorzystaniem systemów ekspertowych, biblioteki powinny uczestniczyć w badaniach w takich obszarach, jak metody reprezentacji wiedzy, automatyczne indeksowanie, automatyczna klasyfikacja i tworzenie abstraktów z wykorzystaniem bazy wiedzy, tworzenie wyspecjalizowanych środowisk programistycznych dla konkretnych dziedzin wiedzy.

\section{Bibliografia}

Ahn, J.; Brusilovsky, P. (2009). Adaptive Visualization of Search Results: Bringing User Models to Visual Analytics. Information Visualization, 8 (3), 167-179.

Ahn, J.; Brusilovsky, P. (2010). What You See Is What You Search: Adaptive Visual Search Framework for the Web [Poster]. In: Proceedings of the 19th international conference on World Wide Web. New York, NY: ACM, 1049-1050.

Ayres, F.H.; Nielsen, L.P.S.; Ridley, M.J.; Torsun, I.S. (1996). USBC (Universal Standard Bibliographic Code): its origin and evolution. Journal of Librarianship and Information Science 28(2), 83-91.

Cieciura, M. (2006). Podstawy technologii informacyjnych z przykładami zastosowań. Warszawa: Vizja Press\&It.

CLAES (2011). The Central lab for Agricultural Expert Systems [online] [14.04.2011], http://www. claes.sci.eg/Home.aspx?TabId=0\&lang=en

Eurovoc (2011). Eurovoc, wielojęzyczny tezaurus Unii Europejskiej [online] [14.04.2011], http://www. vocabularyserver.com/eurovoc/pl/index.php

Expert System Business Information (2011). Expert System. Semantic Technology [online] [14.04.2011], http://www.expertsystem.net/demo_prodotti.asp?lang=1\&id=1554

Grosz, B.; Davis, R. (eds) (2011). A Report to ARPA on Twenty-First Century Intelligent Systems [online]. American Association for Artificial Intelligence [14.04.2011], http://www.aaai.org/Library/ Reports/arpa-report.php

Hawkins, D.T. (1988). Applications of artificial intelligence (AI) and expert systems for online searching. Online 12(1), 31-38.

Hjerppe, R.; Olander, B. (1989). Cataloging and expert systems: AACR2 as a knowledge base. Journal of the American Society for Information Science, 40(1), 27-44.

Klincewicz, K.; Żemigała, M.; Mijal, M. (2012). Bibliometria w zarządzaniu technologiami i badaniami naukowymi [online]. Warszawa: Ministerstwo Nauki i Szkolnictwa Wyższego [15.03.2013], http:// www.nauka.gov.pl/fileadmin/user_upload/20120118_Bibliometria_w_zarzadzaniu_technologiami_i_badaniami_naukowymi.pdf

Kocójowa, M. (2010). Badania interdyscyplinarne bibliotek, informacji naukowej, książki: szansa i utrapienia dla uczonych [online]. W: M. Kocójowa (red.) Biblioteki, informacja, ksiażka: interdyscyplinarne badania i praktyka w XXI wieku. (ePublikacje Instytutu INiB UJ, [14.04.2010]. Dostępny w WWW: http://www.inib.uj.edu.pl//wydawnictwa-iinib-uj/seria-3/07

Kwaśnicka, H. (2000). Sztuczna inteligencja - meandry przeszłości i kierunki dalszego rozwoju. W: J. Tchórzewski (red.) IV Krajowa Konferencja Naukowa nt. Sztuczna inteligencja SzI - 15'2000: badania - zastosowania - rozwój. Siedlce-Warszawa, 27-28 września 2000 r.: materiały pokonferencyjne. Siedlce: Wydaw. Akademii Podlaskiej, 15-22.

Leydesdorff L. (2010). Eugene Garfield and Algorithmic Historiography: Co-Words, Co-Authors, and Journal Names. Annals of Library and Information Studies 57(3), 248-260. 
Leydesdorff, L. (b.d.). Heterogenous network of title words, journal names, and co-authors of Eugene Garfield, 1950-2010 [online]. Title words, journal titles, and coauthor names of 305 publication of Eugene Garfield. 1950-2010 [14.04.2011], http://www.leydesdorff.net/garfield/animation

Lucio-Arias, D.; Leydesdorff, L. (2008). Main-Path Analysis and Path-Dependent Transitions in HistCite-Based Historiograms. Journal of the American Society for Information Science and Technology 59(12), 1948-1962.

MatheMEDics ${ }^{\circledR}$ expert online health software (2011). EasyDiagnosis. Osteoporosis Questions [online] [14.04.2011], http://www.easydiagnosis.com/cgi-bin/expert/quest.cgi?mod=Osteoporosis\&code$=\&$ accept $. x=58 \&$ accept. $y=10$

Michalik, K. (2011). Systemy ekspertowe [online]. AITECH. Artificial Intelligence Laboratory [14.04.2011], http://aitech.pl/content/blogcategory/46/142/lang,ISO-8859-2/

Morris, A.; O'Neill, M. (1990). Library and information science professionals and knowledge engineering. Expert Systems for Information Management, 3(2), 115-128.

Niederliński A. (2000). Regułowe systemy ekspertowe. Gliwice: Wydawnictwo Pracowni Komputerowej Jacka Skalmierskiego.

Nowak, E.J.; Szablowski, B.F. (1984). Expert systems in scientific information exchange. Journal of Information Science 8 (3), 103-111.

Medonet.pl (2011). Audiodiagnoza [online] [14.04.2011], http://www.medonet.pl/testy-i-kalkulatory,autodiagnoza,index.html

Pazzani, M.J.; Brunk, C.A.; Silverstein, G. (1991). A knowledge-intensive approach to learning relational concepts. In: Machine Learning. Proceedings of the Eighth International Workshop on Machine Learning (ML91). San Mateo, CA, USA: Morgan Kaufmann, 432-436.

Pindlowa, W. (1991). Systemy ekspertowe w badaniach nad książką. W: M. Kocójowa (red.) Książka polska w okresie zaborów: wybrane problemy metodologii i dydaktyki bibliologii, bibliotekoznawstwa i informatologii. Kraków: Universitas, 75-104.

Rutkowski, L. (2005). Metody i techniki sztucznej inteligencji. Warszawa: Wydaw. Naukowe PWN.

Silva, S.M. De (1997). A review of expert systems in library and information sciences. Malaysian Journal of Library \& Information Science 2(2), 57-92.

Singh, D.K.; Singh, B.K.; Dubey, Y.P. (1996). Expert systems and their application in library and information systems. DESIDOC Bulletin of Information Technology, 16(4), 9-12.

Sosińska-Kalata, B. (1990). Wykorzystanie technik sztucznej inteligencji we współczesnym bibliotekarstwie i systemach wspomagających wyszukiwanie online. Zagadnienia Informacji Naukowej, 1 (56), 111-138.

Tomaszczyk, J. (2009). Angielsko-polski stownik informacji naukowej i bibliotekoznawstwa. Katowice: Uniwersytet Śląski; Studio Noa.

Tseng, G.; Drenth, H.; Morris, A. (1995). The selection of online databases for UK company information. Journal of Librarianship and Information Science 27(3), 159-170.

Webster (2011). Webster's online dictionary with multilingual thesaurus translation [online] [14.04.2011], http://www.websters-online-dictionary.org/definitions/

Zainib, A.N.; Zaid, N.E.M. (1996). Introducing Maklum: the general reference expert adviser developed for a university library. Malaysian Journal of Library and Information Science, 1(1), 93-107.

Zahir, S.; Chang, Ch. L. (1992). Online-Expert: an expert system for online database selection. Journal of the American Society for Information Science 43(5), 340-357. 


\title{
Expert Systems in Library and Information Science: State of Research, Issues, Examples of Applications
}

\begin{abstract}
Purpose/thesis: The purpose of this paper is to answer the questions of whether and to what extent expert systems are currently used in library and information services. Attention is drawn to the following elements of the information process: acquisition, storage and cataloging/description of information (search characteristics, search instruction), information retrieval (querying, natural language queries), transmission and implementation of information.

Methods: The analysis of the literature acquired through queries in selected databases provided basis for the discussion of research trends in the field of expert systems as one of the methodologies of knowledge management using methods of artificial intelligence: problem solving and representation of knowledge (knowledge generation, valuation and management, knowledge extraction and synthesis in the construction of expertise), ,self-learning”, performance evaluation. In the final part of the paper an attempt was made to identify possible areas of expert systems application in libraries and information centers.

Results: The research helped to specify the number of bibliographic records containing information about expert systems and recorded in selected databases. Expert systems vocabulary presented in the example thesaurus was discussed and the literature of the field was studied.

Conclusions: The quantitative analysis of the literature showed a significant decrease in the number of publications on expert systems after 2010. Nevertheless, the expert systems (both experimental and operational) are used in numerous fields. It is expected that these systems will be used in specialized libraries for the acquisition and codification of knowledge in selected areas of specialization.
\end{abstract}

\section{Keywords}

Expert systems. Information science. Knowledge engineering.

Dr JOLANTA SZULC jest absolwentka Wydziału Filologicznego Uniwersytetu Śląskiego (1991), Wydziatu Teologicznego Katolickiego Uniwersytetu Lubelskiego Jana Pawła II (1997), Wydziału Zarzadzania i Komunikacji Spotecznej Uniwersytetu Jagiellońskiego (2001) oraz Wydziału Mechanicznego i Technologicznego (2008) i Automatyki, Elektroniki i Informatyki Politechniki Śląskiej (2012). W 2003 r. uzyskała stopień doktora nauk humanistycznych w zakresie bibliologii. Pracuje w Instytucie Bibliotekoznawstwa i Informacji Naukowej Uniwersytetu Ślaskiego, od 2006 r. na stanowisku adiunkta. Specjalizuje się w zagadnieniach związanych z organizacją wiedzy, językami informacyjno-wyszukiwawczymi, formalnym i rzeczowym opracowaniem zbiorów, systemami informacyjnymi, a także systemami ekspertowymi i e-learningiem. Jest członkiem Polskiego Towarzystwa Informacji Naukowej oraz International Society for Knowledge Organization, a taki̇e członkiem honorowym Federacji Bibliotek Kościelnych FIDES. Kontakt z autorem: jolanta.szulc@us.edu.pl Instytut Bibliotekoznawstwa i Informacji Naukowej

Uniwersytet Śląski w Katowicach

Plac Sejmu Śląkiego 1

40-032 Katowice

(pok. 314) 